\title{
ДИДАКТИКА, МЕТОДИКА, ПЕДАГОГІЧНА ТЕХНОЛОГІЯ І МОДЕЛЮВАННЯ НАВЧАЛЬНО-ПІЗНАВАЛЬНИХ ПРОЦЕСІВ
}

\footnotetext{
У статті подається логіко-семантичний аналіз та визначається науково достовірна ієрархія понять «дидактика», «методика», «педагогічна технологія». Розкриваються психолого-педагогічні та організачійно-методичні аспекти технологічного моделювання. Запропоновано структурно-функиіональні моделі навчально-пізнавального процесу, покликані забезпечити трунтовність знань.

Ключові слова: дидактика, методика, педагогічна технологія, моделювання навчально-пізнавального процесу, трунтовність знань.

В статье предложен логико-семантический анализ и определяется научно достоверная иерархия понятий «дидактика», «методика», «педтехнология». Раскрыты психолого-педагогические и организаиионно-методические аспекты технологического моделирования. Приведены структурно-функииональные модели учебно-познавательного прочесса, обеспечиваюшие прочность знаний.

Ключевые слова: дидактика, методика, педагогическая технология, моделирование учебно-познавательного прочесса, прочность знаний.
}

There are given the logic-semantical analysis and the scientific reliability of definitions «didactics», «methodology», "pedagogical technology» in this article. There are disclosed psychologic-pedagogical and methodologic-organizing aspects of technological modeling in it. There are proposed structural-functional models of educational process which must provide the strength of knowledge.

Key words: didactics, methodology, pedagogical technology, strength of knowledge, educational modeling.

Поповнення понятійного апарату $є$ постійним i закономірним явищем, яке супроводить безперервний процес розвитку кожної галузі науки. Входження у вжиток тих чи інших конкретних термінів відбувається по-різному. Окремі 3 них виникають як неологізми на ознаменування нововиявлених процесів чи явищ, інші - приходять із споріднених (а то й віддалених) галузей наукових знань у результаті розширення зони впливу останніх. При цьому нові терміни далеко не завжди швидко набувають загального визнання і широкого застосування. В науково-педагогічній літературі досі продовжується наповнення новим змістом понять дидактика, методика викладання, педагогічна технологія. Особливо дискусійною залишається проблема їх ієрархії [2; 8; 9; 10; 12]. Питання грунтовності знань не залишає байдужим теоретиків педагогіки ще з часів першого виходу в світ «Великої дидактики» Яна Амоса Коменського [4]. При цьому не може лишитися непоміченою історична залежність дефініцій названої складної педагогічної категорії [4; 5; 6; 7]. Необхідність систематизації наявних теоретичних положень та обгрунтування пропозицій щодо практичної реалізації проблеми зумовило формулювання мети пропонованого дослідження: визначити на основі логіко-семантичного аналізу науково достовірної ієрархії понять «дидактика», «методика викладання», «педагогічна технологія» та розробка структурно-функціональних моделей навчальнопізнавального процесу, спрямованих на забезпечення грунтовності знань учнів (студентів).

Утвердження у вітчизняній педагогіці поняття «освітня технологія» триває вже десятки років, але ще й досі залишається предметом наукових дискусій і різнотлумачень.

Досить поширеним є намагання синонімізувати поняття «технологія» і «методика викладання», віднісши перше 3 них на рахунок данини моді. Щоб розібратися в облудності подібних намагань, здавалося б досить звернутися до відомого і влучного, як на нашу думку, висловлювання В. Гузеєва про те, що методика відповідає на три запитання - чому, навіщо і як навчати, тоді як технологія лише на одне 3 них: як? Однак той факт, що сказане видається не зовсім переконливим для певного кола опонентів, зобов'язує нас удатися до детальнішого з'ясування проблеми.

3 позиції формально-системного підходу, питання ієрархії понять дидактика, методика, технологія вичерпує розроблена нами схема співвідносного підпорядкування перелічених та інших споріднених термінів [3, с. 90 - 96]. Подальші пошуки істини переконують у доцільності розгляду співвідношення термінів методика i технологія у двох площинах - змістовній і функціональній. За змістовною субординацією поняття технологія вужче, підтвердженням чого $є$ наведене вище посилання, а логічним відображенням - згадана схема. За функціональним же виявленням, технологія - поняття ширше порівняно 3 методикою, оскільки, не будучи прив'язаним до конкретного навчального матеріалу і часових параметрів, воно сповнюється більшою дидактичною наснагою й об'єднує в собі педагогічні рекомендації, які виходять за межі тих чи інших навчальних дисциплін, а, відповідно, й методик їх викладання. Спробуємо конкретизувати сказане. Методика викладання того чи іншого предмета вимагає, щонайперше, визначення змісту навчання і наповнення цього змісту конкретним матеріалом у межах уроку, теми, розділу, навчального року і тощо. Зміст і особливості навчального матеріалу зу-мовлюють визначення мети і завдань кожного заняття, вказівок і рекомендацій, щодо 
того, як працювати з тим чи іншим матеріалом і забезпечити результативність засвоєння програми 3 навчальної дисципліни.

Технологія навчання, не обмежена вузькими рамками програмових вимог (навіщо і що вивчати), покликана, враховуючи загальні теоретичні основи організації педагогічної взаємодії суб’єкта i об'єкта процесу навчання, визначити якісні характеристики оптимального функціонування таких важливих понять, як принципи дидактики, структурування навчального матеріалу і навчальнопізнавальної діяльності, практична спрямованість навчального процесу та методи і форми його організації.

Наведене вище авторське тлумачення понять може викликати цілком передбачуване зауваження: якщо технологія не прив'язана до конкретного змісту чи специфіки навчального матеріалу, то це дидактика. Не маючи жодних підстав ототожнювати наведені поняття, ми змушені, усе ж, визнати, що на своєму загальнофункціональному рівні технологія дійсно тяжіє більше до дидактики, аніж до окремих методик. Але це, цілком справедливе, з одного боку, тяжіння, з іншого - виглядає досить суперечливим, оскільки дидактика - теорія навчання, тоді як технологія більшістю спеціалістів сприймається, перш за все, як процес. Та й ми самі говоримо нині про функціональний (діяльнісний) рівень технологічного забезпечення навчального процесу.

Подальше цілеспрямоване заглиблення в сутність педагогічних явищ i аналізованих термінів закономірно приводить до необхідності їх осмислення в контексті діалектичної взаємодії філософських категорій «теорії» $\mathrm{i}$ «практики». Забігаючи наперед, зауважимо, що саме такий підхід $є$ єдино правильним і здатним уберегти дослідника від паралогізму у міркуваннях щодо взаємозв'язку дидактики і технології навчання.

Віднайдення ознак спорідненої залежності у двох групах попарно взятих термінів (на основі логічного виявлення аналогій) стало підтвердженням наявності гіпотетично передбачуваного нами паралелізму в співвідношенні понять «теорія і практика» та «дидактика і технологія».

Вдамося до ілюстрацій. Як відомо, теорія - сукупність абстрактних пізнавальних образів у вигляді уявлень, понять, ідей, принципів, концепцій; система вірогідних знань у певній галузі науки, які скеровують і організовують діяльність людини. Практика - це і є сама діяльність, спрямована на перетворення оточуючої дійсності. Відповідним чином, дидактика (теорія навчання) - наука про те, як організувати навчальну діяльність, технологія - виважена схема дій (підготовлена для практичного втілення інструкція), ефективність якої забезпечується дотриманням основоположних ідей і законів науки. Конкретніше, цілеспрямований пошук і обгрунтування «схеми дій», як процесу теоретичного конструювання навчально-пізнавальної діяльності, $є$ сферою дидактики. «Схема дій», як готова до використання виважена інструкція 3 іiі подальшою практичною реалізацією - це технологія навчання. Потреби системи освіти вимагають пошуку дотичних точок функціонального зв’язку дидактики і технології. Своєрідним об’єднувальним, відносно двох попередніх, поняттям можна вважати технологічне моделювання навчально-пізнавальної діяльності. Технологічне моделювання - це складне педагогічне явище, процес і результат теоретичного програмування 3 прогностичними передбаченнями, яке відіграє нормативну роль i реалізується у практичному творенні за підготовленою калькою однотипних за алгоритмом i, при потребі, повторюваних у часі актів діяльності. При цьому слід підкреслити, що йдеться про загальнодидактичний аспект проблеми забезпечення постійного зростання ефективності навчання. Конкретні методичні спроби створити мобільний пізнавальний процес 3 гарантованими результатами проявлялися, свого часу, в різних варіантах програмованого навчання. Останнє, як відомо, не виправдало надмірно оптимістичних сподівань своїх прихильників і не зумовило глобальні революційні перетворення в галузі освіти. Однією 3 причин цього було те, що методика програмованого навчання передбачала повне управління навчальним процесом 3 підпорядкуванням волі вчителя (а через нього й учнів) змістові, дозуванню, послідовності і способам викладу конкретного матеріалу. За таких умов для педагогічної творчості не залишалося місця, i, не випадково, роль «наставника» у різних варіаціях програмованого навчання 3 таким же успіхом переймали на себе машина чи спеціальний підручник.

У нашому випадку технологічна модель, урешті-решт, також повертається до методичної (змістовної) площини і наповнюється конкретним матеріалом, але остаточний сценарій кожного заняття твориться самим педагогом. Таким чином, 3 одного боку, забезпечується дотримання загальних закономірностей і принципів оптимальних дидактичних умов результативного навчання, а 3 іншого, - стимулюється повноцінне використання особистого педагогічного досвіду і таланту вчителя (викладача).

Досить ілюстративним прикладом чинної педагогічної технології $\epsilon$ всім відома сьогодні рейтингова система, яку дехто 3 молодих освітян помилково вважає ровесницею доби офіційного приєднання України до Болонського процесу. Для непоінформованих нагадаємо, що успішний досвідом запровадження рейтингового навчання, скажімо, в Харківському педагогічному університеті оприлюднено І. Прокопенком і В. Свдокимовим в одній із спільних праць ще в 1995 році. Автори демонструють здобутки своїх колег на прикладі викладання курсу педагогіки, однак запропоновану технологію можна успішно застосовувати при вивченні будь-яких навчальних дисциплін. Алгоритм простий. Після ознайомлення на вступному занятті з навчальним планом та 
програмою, тематикою практично-семінарських занять і рефератів, графіками контрольних робіт, тестувань, колоквіумів та самою технологією рейтингової системи студентам пропонують варіанти вивчення курсу й оцінювання їх роботи. Весь курс оцінюється 100 балами, з яких на іспит припадає тільки 30. Найвищий бал - оцінка «відмінно» - виставляється студентові, котрий набрав 85 і більше балів, «добре» - за 70-84 бали, «задовільно» - за 55-69 балів. «Незадовільно» отримує той, хто набрав менше 55 балів. При цьому суму балів, необхідну для отримання, навіть відмінної оцінки, студент має можливість набрати протягом семестру (без складання екзамену). Певною сумою балів, обумовленою до початку вивчення курсу, оцінюються виконання обов'язкових i додаткових рефератів, складання колоквіумів, контрольних робіт, виступи, повідомлення і доповнення на семінарських заняттях тощо [9, с. 7-8].

Як бачимо, незалежно від навчальної дисципліни та іï змісту рейтингова технологія здатна забезпечити об’єктивне оцінювання наслідків праці студента (учня) протягом тривалого відрізку часу. Подібним чином можна технологічно програмувати окремі ланки навчально-виховного процесу, такі як оптимальна система опитування, логічна обробка й кодування навчального матеріалу 3 метою його довготривалого запам'ятовування і подібне. Можливі й технології цілеспрямованого вирішення окремих важливих завдань оптимізації навчального процесу, такі як, технологія активізації навчально-пізнавальної діяльності на занятті, технологія формування пізнавальної самостійності школярів (студентів), розвитку дослідницьких інтересів тощо.

Досить важливим, з точки зору комплексного розв’язання проблеми підвищення результативності педагогічної діяльності, є технологічне моделювання навчально-пізнавального процесу в цілому, точніше, різних його якісних рівнів: інформативно-відтворюючого, інтерпретивного, соціально значущого - творчого. Структуру останніх розгорнуто представлено в монографії автора [7, с. 56-65].

Подібні моделі, відображаючи педагогічну діяльність у нормативному плані, створюють передумови для перетворення навчання на технологічний процес із гарантованими позитивними результатами.

Відправною точкою моделювання діяльності повинна стати якась вихідна ідея, котра вже на рівні цілеутворення має набути ознак стратегічного орієнтиру, чим забезпечиться перетворення технологічної моделі в логічно замкнену діяльнісну систему. Для прикладу розглянемо теоретичні основи технології грунтовного засвоєння навчального матеріалу. Відповідно, в контексті подальшої розмови роль об'єднувальної має перейняти на себе ідея грунтовності знань. Не вдаючись у подробиці, нагадаємо, що грунтовність знань - складне динамічне явище, багатозначне поняття, яке, 3 одного боку, є дидактичним принципом, а з іншого - якісною характеристикою знань. При цьому слід пам'ятати, що слово грунтовність - семантично ширше, аніж міцність (у російському варіанті «прочность знаний») i термінологічно відповідає введеному свого часу Ю. Бабанським поняттю «міцність і дієвість знань» (рос. «прочность й действенность знаний»).

Усім відомо, що грунтовність, як якісна характеристика знань, - багатопланове і багатоступінчате утворення. Отож необхідною умовою технологічного моделювання дидактичних процесів $\epsilon$ осмислення рівневої структури аналізованого поняття 3 подальшим виокремленням того чи іншого рівня, як основи для визначення мети і завдань кожного конкретного етапу навчально-пізнавальної діяльності.

Нульовою точкою відліку при характеристиці будь-яких якісних показників знань є повна їх відсутність. Першим рівнем, достатнім для елементарного оціночного судження, можна вважати впізнавання засвоєного раніше навчального матеріалу та пригадування тих чи інших положень за допомогою навідних запитань. Другим, і вже прийнятним з точки зору результативності навчальновиховного процесу, можна вважати рівень знань, який забезпечує їх репродуктивне відтворення $\mathrm{i}$ застосування в стандартних ситуаціях. Наступними і якісно вищими етапами у рівневій характеристиці знань можна вважати свідоме, повне чи вибіркове відтворення й оперативне функціонування; здатність до осмисленого використання знань на міжпредметній основі, усвідомлення способів своєї навчально-пізнавальної діяльності, оволодіння уміннями вибирати раціональні і конструювати «нові» способи дій; творче застосування знань і способів дій з розвитком здібностей здійснювати їх перенесення із навчально-пізнавальної в інші сфери життєдіяльності.

Зрозуміло, що перші два з умовно охарактеризованих вище рівнів «грунтовності» знань не можуть бути обрані орієнтирами діяльності. Визначившись у доступності одного з інших, можна переходити до формулювання конкретних цілей і завдань відповідного етапу навчально-пізнавального процесу. Аналіз спеціальних публікацій І. Харламова, В. Питюкова, І. Підласого, Т. Ільїної, В. Данюшенкова, В. Беспалька, В. Рєпкіна, Л. Прокопенка та В. Свдокимова переконує в тому, що при загальній спорідненості підходів названий аспект проблеми найбільш повно і вдало розкритий у працях саме двох останніх авторів [3; 9].

Ми поділяємо позицію названих учених у тому, що технологічно виправданим $\epsilon$ лише формулювання мети шляхом прогнозування результатів навчання, які виражаються в діях учнів (студентів), визначаються і підлягають перевірці.

Давно слід зректися традицій визначати мету через зміст навчальної інформації (вивчити поняття, явища); через діяльність учителя (ознайомити учнів 3 фактами, подіями); через внутрішні процеси $і$ 
зрушення в розвитку учнів (навчити аналізувати досліджуваний об'єкт); через зовнішнє вираження навчальної діяльності (дослідження будови речовини, структури предмета).

Не залишає місця для сумнівів і точка зору, згідно 3 якою надто узагальнена і «недостатньо інструментальна» мета вимагає поетапної чи поопераційної конкретизації. Класичним прикладом педагогічної казуїстики можна вважати абстраговано-глобалізоване формулювання мети за зразком «учитися критично мислити при читанні тексту». Зовсім інакше, 3 точки зору мобільності та потенціальної результативності, виглядає система «проміжних цілей»: знаходити відмінності між фактичними відомостями i оціночними судженнями; виділяти причинно-наслідкові зв’язки; знаходити помилку в судженні; відрізняти суттєві докази від неістотних; розмежовувати переконливі i поверхові оцінки подій чи явищ; формулювати на основі опрацьованого тексту обгрунтовані висновки.

На основі такої градації мети і вивчення можливостей конкретного матеріалу, специфічних характеристик дитячого колективу, індивідуальних особливостей учителя та учнів легко визначити конкретні і підконтрольні завдання кожного заняття.

Останнє дозволить сконцентрувати зусилля педагога та його вихованців і спрямувати їх діяльність на досягнення грунтовного засвоєння навчального матеріалу.

Залежно від завдань відповідного етапу навчально-пізнавального процесу і його зорієнтованості на доступний у тих чи інших умовах рівень грунтовності знань визначається практична спрямованість навчання, що також є важливою складовою технологічного програмування.

Якщо проектується педагогічний процес із домінуючими ознаками інформативно-відтворюючого рівня організації навчально-пізнавальної діяльності (з орієнтацією на забезпечення репродуктивного відтворення знань i їх використання в стандартних ситуаціях), то практична спрямованість навчального процесу може обмежуватися: а) засвоєнням учнями відомостей практичного характеру 3 різних сфер життя; б) формуванням у школярів простих i узагальнених умінь i навичок; в) оволодінням інформаційними загальнонавчальними уміннями (спостереження, робота 3 друкованим і усним словом), практичними вміннями (читати, писати, рахувати, виконувати трудові операціі), інтелектуальними (виконувати завдання на відтворення і відновлення); г) мотивацією необхідності формування дисциплінованості, почуття відповідальності, як необхідної умови успішного навчання.

Якщо ж передбачається втілення в практику, скажімо, моделей інтерпретивного рівня організації навчально-пізнавальної діяльності і, відповідно, досягнення якісно вищих показників грунтовності знань, то практична спрямованість педагогічного процесу набуває такого виразу: а) цілеспрямоване формування у учнів (студентів) умінь свідомо використовувати набуті знання і способи дій для оволодіння новими; б) навчання відшукувати різні, у тому числі найраціональніші, способи розв’язання навчальних завдань; в) розвиток здібностей осмислювати навчальні ситуації, застосовувати відомі і, при потребі, вдаватися до рекомбінаційного конструювання нових способів дій; г) формування широкого спектра загально дидактичних умінь.

Однією з основних ланок структурно-функціональної моделі навчально-пізнавального процесу $є$ чітке технологічне програмування діяльності учителя й учнів, 3 визначенням суб'єктно-об'єктної специфікації і оптимальних параметрів педагогічної взаємодії. Причому оптимальність і доцільність створюваної моделі зростає за умови виваженого передбачення всіх можливих ситуацій і наявності в арсеналі дій суб'єкта педагогічного процесу інструментарію попередження критичних відхилень від програми діяльності. Технологія, в ідеальному варіанті, мала б виключити саму можливість «критичних станів», та оскільки ми маємо справу з «живим матеріалом», то необхідно, обмеживши до мінімуму кількість відхилень від стратегічної лінії, усе ж передбачати необхідні механізми коригування діяльності об'єкта і безболісного повернення їі в заплановане русло. Все, про що йшлося вище, зумовлює визначення системи методів навчання, вибір форм організації навчального процесу, механізмів оцінювання поточних і кінцевих результатів учіння. Залежно від орієнтації на той чи інший рівень грунтовності знань, певними особливостями наповнюється, навіть, домашнє завдання, яке може зводитися до своєрідного позаурочного дублювання дій, засвоєних на занятті, а може стати специфічною складовою підготовки до пошукової і дослідницької діяльності на наступному занятті чи формою творчої пізнавальної самодіяльності.

Зі змісту статті робимо висновок про те, що виважений науковий підхід до організації навчальнопізнавальної діяльності дає можливість чітко спланувати усі ії основні параметри (від формулювання мети до прогнозування заключних результатів) і на цій основі створити технологічну структурнофункціональну модель педагогічного процесу. Більше того, такий підхід забезпечує динамічний розвиток навчально-пізнавальної діяльності в умовах організованого навчання від нижчих до вищих рівнів, що в свою чергу обумовлює вирішення одного 3 найважливіших освітніх завданьгрунтовного засвоєння учнями (студентами) програмового матеріалу.

\section{Література}

1. Беспалько В. П. Основы теории педагогических систем / В. П. Беспалько. - Воронеж : ВГУ, 1977. 2. Беспалько В. П. Слагаемые педагогической технологии / В. П. Беспалько. - М., 1989. 3. Засоби навчальної та науково-дослідної роботи: [збірник наукових праць] / за ред. В. І. Свдокимова, О. М. Микитюка. - Харків : Харківський державний педагогічний університет, 1997. - С. 90-96. 4. Коменский Я. А. Избр. пед. соч.: В 2т. - 
Т. 1 / Я. А. Коменский. - М. : Учпедгиз, 1939. - 320 с. 5. Одерий Л. П. Основы системы контроля качества обучения / Л. П. Одерий. - К., 1995. 6. Оконь В. Введение в общую дидактику / В. Оконь. - М. : Высшая школа, 1990. 7. Онопа В. Н. Дидактические условия прочности усвоения учебного материала школьниками: [монография] / В. Н. Онопа. - Днепропетровск : Пороги, 1997. - 95 с. 8. Падалка О. С. Педагогічні технології / О. С. Падалка, А. С. Нісімчук та ін. - К., 1995. 9. Прокопенко І. Ф. Педагогічна технологія: [навч. видання] / I. Ф. Прокопенко, В. І. Свдокимов. - Харків, 1995. - С. 7-8. 10. Свириденко С. С. Современные информационные технологии / С. С. Свириденко. - М., 1989. 11. Тихонов И. Л. Программирование и технические средства в учебном процессе / И. Л. Тихонов. - М., 1970. 12. Шеледков К. К. Дидактические системы и перспективы их реализации / К. К. Шеледков, Н. Г. Свиридов. - М., 1974. 